\title{
Agronomic methods for mountain grassland habitat restoration for faunistic purposes in a protected area of the northern Apennines (Italy)
}

\author{
Francesco Cervasio $^{(1)}$, Giovanni \\ Argenti $^{(1)}$, Marco Genghini ${ }^{(2)}$, \\ Maria Paola Ponzetta ${ }^{(1)}$
}

\begin{abstract}
The abandonment of pastures often leads to a remarkable deterioration of grasslands, caused by the spread of intrusive, herbaceous and woody species which reduces the general quality of pastures. Different treatments aimed at improving the grassland and enhancing the forage quality of herbaceous resources have been developed to face this problem. We report the results of a five-year experiment conducted in a protected area of central Italy (the "Laghi di Suviana e Brasimone" regional park) on an abandoned pasture inside a beech forest encroached by intrusive species (mainly bracken). We analyzed the effect on sward's specific composition and grazing value of two agronomic factors: (i) the establishment method (ploughing followed by sowing of a forage mixture versus no intervention), and (ii) the number of cuts performed on vegetation during the growing season $(0,1$ or 2 cuts). Plots were arranged according to a split-split-plot experimental design with three replications, with the sampling dates as the main factor, the establishment technique as the subplot factor, and the number of cuts as the sub-subplot factor. In each plot, data were recorded once a month from June to September every year from 2006 to 2010, in order to assess the botanical composition and the quality of the sward. The main pastoral and botanical parameters of pastures were significantly affected by both cutting and sowing. Establishment by sowing significantly reduced the presence of bracken, even with no cuts, with strong effects on the qualitative value of the pasture. A single cut resulted in an efficient recovery of the pasture as compared to cutting twice, especially in sown plots. Our results confirmed that the regular and continued maintenance of the recovered areas is crucial to ensure the long-term preservation of the results achieved by the improvements.
\end{abstract}

Keywords: Botanical Composition, Grasslands, Grazing Value, Pteridium aquilinum, Sowing et al. 2012). This evolution affects not only the floristic composition of pastures (Rook \& Tallowin 2003, Cervasio et al. 2009), but also other important aspects such as biodiversity, ecological service provision and the forage quality of wooded grasslands (Mack et al. 2000, Argenti et al. 2012, Bagella et al. 2013, McAllister et al. 2014, Rossetti et al. 2015). In addition, the replacement of open areas by woody species has a remarkable impact on the homogeneity of territory, in
(1) Department of Agrifood Production and Environmental Sciences (DiSPAA), University of Florence, p.le delle Cascine 18, I-50144 Firenze (Italy); (2) Istituto Superiore per la Protezione e la Ricerca Ambientale (ISPRAA), v. Ca' Fornacetta 9, I-40064 Ozzano dell'Emilia, Bologna (Italy)

@ Giovanni Argenti (giovanni.argenti@unifi.it)

Received: Nov 30, 2014 - Accepted: Sep 02, 2015

Citation: Cervasio F, Argenti G, Genghini M, Ponzetta MP (2016). Agronomic methods for mountain grassland habitat restoration for faunistic purposes in a protected area of the northern Apennines (Italy). iForest 9: 490-496. - doi: 10.3832/ifor1515-008 [online 2016-0107]

Communicated by: Andrea Cutini terms of fragmentation of such habitats (Laiolo et al. 2004, Lengyel et al. 2008). For these reasons, conservation actions are often planned and implemented in order to restore the grassland ecosystems (Cox et al. 2007, Stewart et al. 2008), particularly in susceptible environments such as upland regions or protected areas (Genghini \& Capizzi 2005).

The most common consequence of pasture abandonment is their colonization by bracken (Pteridium aquilinum (L.) Kuhn), one of the most invasive plants, which develops on acidic soil in many regions of the world (Marrs \& Watt 2006, Smart et al. 2007, Cox et al. 2008). Bracken encroachment compromises the forage quality of pastures (Le Duc et al. 2000a) and produces a dense litter hampering the establishment of other species (Frankland 1976, Birch et al. 2000), thus lowering species diversity in these areas (Pakeman \& Marrs 1992). For the above reasons, the recovery of the original plant community is a major issue in these environments. Nevertheless, areas encroached by bracken are difficult to restore and improve, since bracken produces a dense frond cover (Marrs et al. 2000) and has rhizomes with large carbo- 


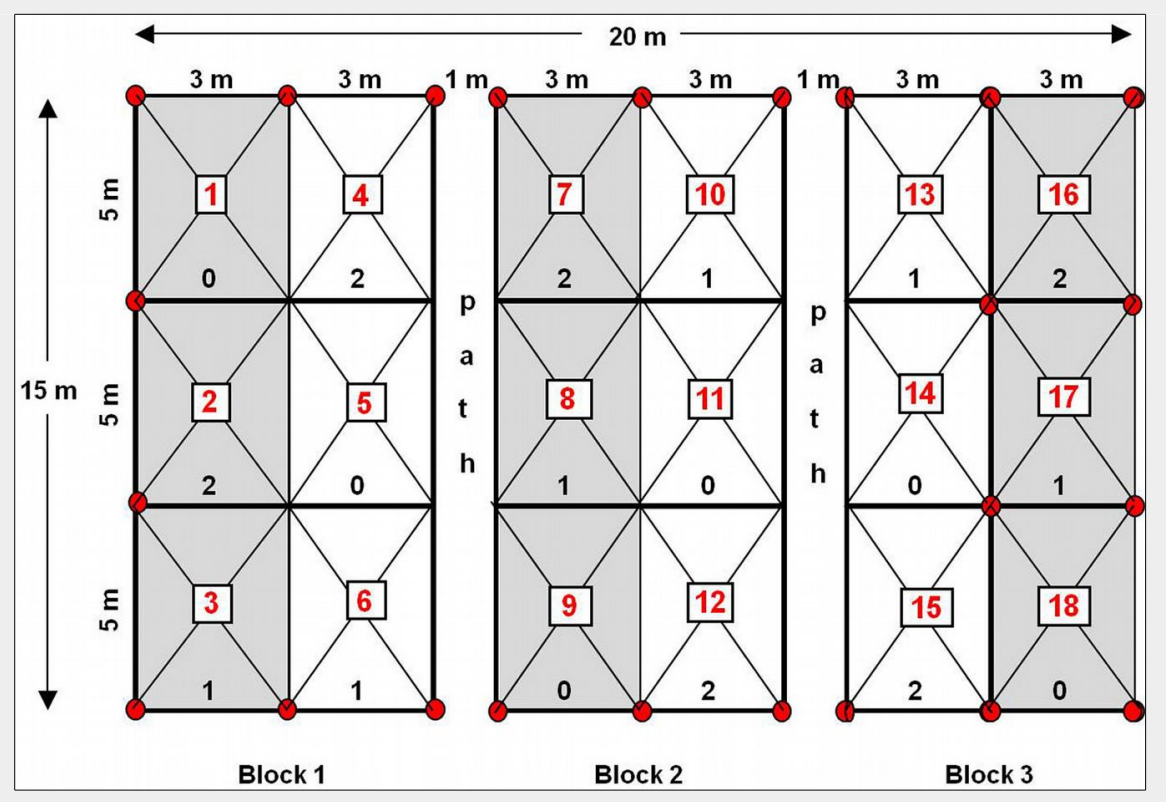

Fig. 1 - Arrangement and size of plots used in the experiment. Black numbers in each plot (box) indicate the number of cuts applied $\left(0,1\right.$, or 2 cuts year $\left.{ }^{-1}\right)$. Grey boxes represent the plots where sowing was applied, while white boxes are plots with no sowing.

hydrate reserves, favoring its resprouting (Le Duc et al. 2003).

The operations carried out for bracken removal involve both chemical (Lowday \& Marrs 1992, Stewart et al. 2007) and/or mechanical interventions (Godefroid et al. 2007, Ponzetta et al. 2010). Mechanical intervention is more suitable in fragile environments, such as protected areas (Argenti et al. 2012), as it reduces the strength of rhizomes and their carbohydrate content. This practice, combined with frond cutting in the periods of higher consumption of reserves, allows a consistent reduction of bracken diffusion (Pienkowski et al. 1998, Marrs et al. 2000). The phenological stage at the time of cutting and the number of cuts are key factors for the efficient removal of bracken, since they can hinder the recovery of reserves in the rhizomes (Cantiani \& Talamucci 1985, Marrs et al. 1992). After the mechanical elimination of undesirable species, a forage species mixture is sometimes sown to rapidly enrich species composition and improve the forage quality of the restored areas ( $\mathrm{Di}$ Tomaso et al. 2010). To reduce sowing failure and attain revegetation goals, the choice of a mixture of species well-adapted to site conditions is critical (Stevens 2004).

The main objective of this investigation was to provide useful and practical information on the techniques for establishing and maintaining grassland restoration in protected areas. To this purpose, an experimental trial was carried out in an abandoned pasture within a beech forest, which was highly encroached by Pteridium aquilinum. The experiment area was monitored for several years following the recovery to properly assess the canopy's response to the studied treatments. Agronomic factors involved in the experiment were the soil tillage and seeding of a forage mixture, combined with the number of cuts of the bracken fronds along the growing season. The main focus was on the effectiveness of different grassland restoration methods, in order to provide options for the maintenance of these habitats, and to analyze the evolution of the restored grasslands since pasture recovery (which is fairly uncommon in the literature), with particular attention to botanical and qualitative aspects.

\section{Materials and methods}

The experimental site "Poggio alle Vecchiette" is a grassland area inside a beech forest that has been highly encroached by bracken (Cervasio 2009). It is located in the "Laghi di Suviana e Brasimone" regional park (northern Apennines, Emilia Romagna, Italy). The site $\left(44^{\circ} 07^{\prime} \mathrm{N}, 11^{\circ} 05^{\prime} \mathrm{E}, 1140\right.$ $\mathrm{m}$ a.s.l.) is mainly flat, faces south-west on sandstone soil, and is dominated by Pteridium aquilinum since grassland abandonment (Cervasio 2009). Previous studies carried out in the same area focused on the efficiency of different restoration techniques based on the qualitative and pastoral characteristics of herbaceous resources encroached by bracken (Cervasio et al. 2007, 2009, Ponzetta et al. 2010, Argenti et al. 2012). The recovery of encroached grasslands was mainly undertaken to improve habitat for wild animals, as the area represents one of the most important sites for red deer in the northern Apennines (Argenti et al. 2012).

In the experimental area (about 0.2 ha wide), 18 plots ( $3 \times 5 \mathrm{~m}$ wide) were delimited and subjected to different agronomic treatments (Fig. 1):

- Sowing method. Half of the plots were ploughed (30 cm depth) and then seeded with a suitable forage mixture, composed as follows: Phleum pratense (cv. CLIMAX, $10 \%$ by seed weight); Festuca rubra (ECHO, 25\%); Dactylis glomerata (AMBA, 25\%); Lolium perenne (BELIDA, 20\%); Trifolium repens (HUIA, 10\%); Trifolium hybridum (AURORA, 5\%); and Lotus corniculatus (LEO, 5\%). Sowing was performed on April $23^{\text {rd }} 2006$ with a total seed rate of $80 \mathrm{~kg}$ ha'. ${ }^{-1}$. The other half of the plots was not subjected to any ploughing or seeding, i.e., it represented the natural condition in the area;

- Number of cuts. Plots were subjected to a different number of cuts of vegetation ( 0,1 or 2 cuts) along the growing season. The first cut was done when bracken fronds were completely opened (about the beginning of July), while the eventual second cut was performed on new shoots, before the reconstitution of reserves in the rhizomes (about the beginning of September).

Data collection was performed every month during the growing season (June, July, August and September) over the period 2006-2010. The plots were arranged as a split-split-plot, with a complete randomized block design and three replicates (Gomez \& Gomez 1984). The sampling date was the main factor, sowing was the subplot factor, and the number of cuts represented the sub-subplot factor (Fig. 1). To avoid grazing on experimental plots, the site was completely fenced with a mesh net $2.5 \mathrm{~m}$ high.

In each plot the following parameters were recorded at each sampling date:

- the botanical composition, along a diagonal transect of each plot, according to the method of Daget \& Poissonet (1969), in order to quantify the absolute frequency of each species. This was used to estimate the specific contribution ( $S C$ ), i.e., the relative occurrence of a given species in the sward, including the bare soil (Argenti \& Lombardi 2012). The floristic richness of the canopy was estimated as the number $(N)$ of species detected along the transects;

- the grazing value ( $G V)$, a synthetic parameter to estimate pasture quality based on the botanical and qualitative characteristics of the herbaceous species. It was calculated for each transect according to Daget \& Poissonet (1972) as follows (eqn. 1):

$$
G V=0.2 \cdot \sum\left(S C_{i} \cdot S I_{i}\right)
$$

where $S I$ is a specific index ranging from o to 5 , which summarizes the forage value of a species and takes into account its quality, palatability and productivity (Roggero et al. 2002, Cavallero et al. 2007). The analysis of the botanical composition of pastures was performed by aggregating single species values into functional groups, represented by species belonging to grasses and legumes (families with highest forage importance) and species belonging to 
other botanical families, as is usually performed in pastoral research (Cavallero et al. 2002). The bracken contribution was taken into account, separately.

ANOVA was performed to test the effects of the sampling date, the agronomic treatments (sowing and number of cuts) and their interactions, as summarized in Tab. 1. The sampling date was introduced in the model to take into account possible seasonal weather variations occurred across the five-year survey. All factors were considered as fixed. Comparison of the means was carried out by the post-hoc Tukey's test. All the analyses were performed using the GLM procedure of the $\mathrm{SAS}^{\oplus}$ statistical software (SAS 2003).

\section{Results}

Measurements taken during five years of observation (2006-2010) provided information on the effect of treatments designed to control bracken infestation, i.e., both the botanical composition of the sward and its productivity as fodder. The sampling date effect was significant for all parameters. Both agronomic treatments (sowing and number of cuts) significantly affected the analyzed variables. Moreover, in many cases the interactions between factors were significant (Tab. 2). With the exception of the SC of legumes, all the vegetation components (in terms of presence) and grazing values were strongly affected by the tested factors or by their interactions. On the contrary, factors involved in the experiment had a less clear effect on the floristic richness.

The effect of agronomic factors (sowing and/or cutting) on the specific contribution of bracken in the sward is reported in Fig. 2. Regardless of sowing, bracken abundance dramatically decreases after just one vegetation cut. Indeed, no significant differences were observed between the effects of 1 or 2 cuts along the season, as 1 cut was sufficient to improve the botanical composition of the grassland. Moreover, sowing generally resulted in a remarkable reduction of bracken abundance as compared to the control, regardless of the cutting regime.

Fig. 3 shows the effects of the same factors on the grazing value $(G V)$ of the experimental plots. Even in this case, cutting significantly increased the grazing value of both sown and non-sown plots. The effect of the cutting treatment was greater in the non-sown plots, with marked differences between 2 cuts, 1 cut and no cutting, as 2 cuts were necessary to achieve a general improvement in the grassland composition. On the other hand, in the plots subjected to sowing one cut was enough to obtain and maintain a high level of pasture quality, with no differences with plots that were cut twice.

Regarding the evolution of the specific contribution $(S C)$ of grasses over time, the combined effects of sowing and cutting regimes were observed as early as the se-
Tab. 1 - Outline of the ANOVA for the experiment with sources of variation and their degrees of freedom (df). (a, b, c): appropriate errors used to test the significance of different factors or their combination.

\begin{tabular}{lc}
\hline Source of variation & df \\
\hline Replication & 2 \\
Sampling date & 19 \\
Error (a) & 38 \\
Sowing & 1 \\
Sampling date $\times$ sowing & 19 \\
Error (b) & 40 \\
Number of cuts & 2 \\
Sampling date $\times$ number of cuts & 38 \\
Sowing $\times$ number of cuts & 2 \\
Sampling date $\times$ sowing $\times$ number of cuts & 38 \\
Error (c) & 160 \\
Total & 359 \\
\hline
\end{tabular}

Tab. 2 - Results of ANOVA for sampling date, sowing and number of cuts, and their interactions. (SC): specific contribution; $(N)$ : number; (ns): not significant; $\left({ }^{*}\right)$ : $P<0.05$; $(* *): P<0.01$.

\begin{tabular}{|c|c|c|c|c|c|c|c|c|}
\hline \multirow[b]{2}{*}{ Source of variation } & \multicolumn{4}{|l|}{ SC } & \multicolumn{3}{|l|}{$N$} & \multirow[b]{2}{*}{$\begin{array}{c}\text { Grazing } \\
\text { value }\end{array}$} \\
\hline & 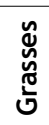 & 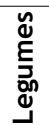 & 命 & 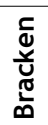 & 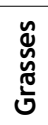 & 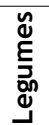 & 号 & \\
\hline Sampling date & $* *$ & $* *$ & $* *$ & $* *$ & $* *$ & $* *$ & * & ** \\
\hline Sowing & $* *$ & $* *$ & $* *$ & $* *$ & ** & $* *$ & $* *$ & ** \\
\hline Number of cuts & $* *$ & * & $* *$ & $* *$ & $* *$ & $* *$ & $* *$ & ** \\
\hline Sampling date $\times$ sowing & $* *$ & $* *$ & * & $* *$ & ** & $* *$ & * & ** \\
\hline Sampling date $\times$ number of cuts & $* *$ & ns & $* *$ & $* *$ & ns & $* *$ & ns & ** \\
\hline Sowing $\times$ number of cuts & $* *$ & * & $* *$ & $* *$ & ns & ns & $* *$ & ** \\
\hline Sampling date $\times$ sowing $\times$ number of cuts & $* *$ & ns & $* *$ & $* *$ & ns & $* *$ & ns & * \\
\hline
\end{tabular}

cond year (Fig. 4a), when a remarkable dif- plots. In the subsequent years, $S C$ of the ference between the effect of cuts ( 1 or 2 ) control plots (no sowing, no cuts) decreaand no cuts was detected in the non-sown sed over time, whereas the occurrence of

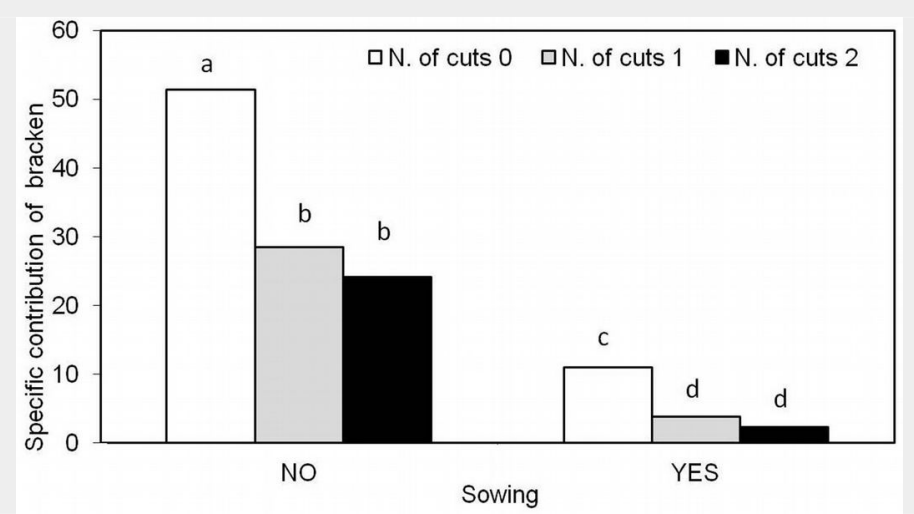

Fig. 2 - Effect of the interaction between sowing and the number of cuts on the average specific contribution of bracken. Bars labeled with the same letter are not significantly different after Tukey's test ( $P>0.05)$.

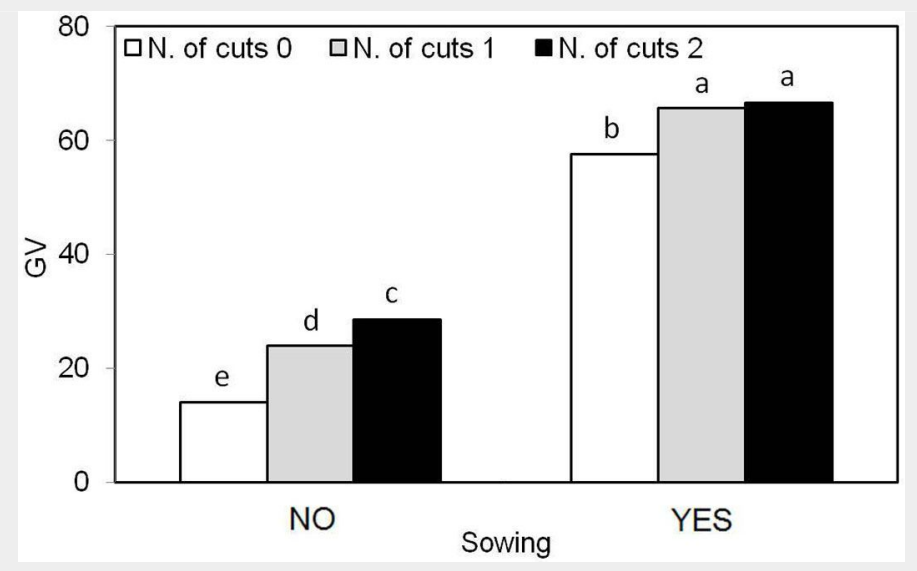

Fig. 3 - Effect of the interaction between sowing and the number of cuts on the average grazing value $(G V)$. Bars labeled with the same letter are not significantly different after Tukey's test $(P>0.05)$. 


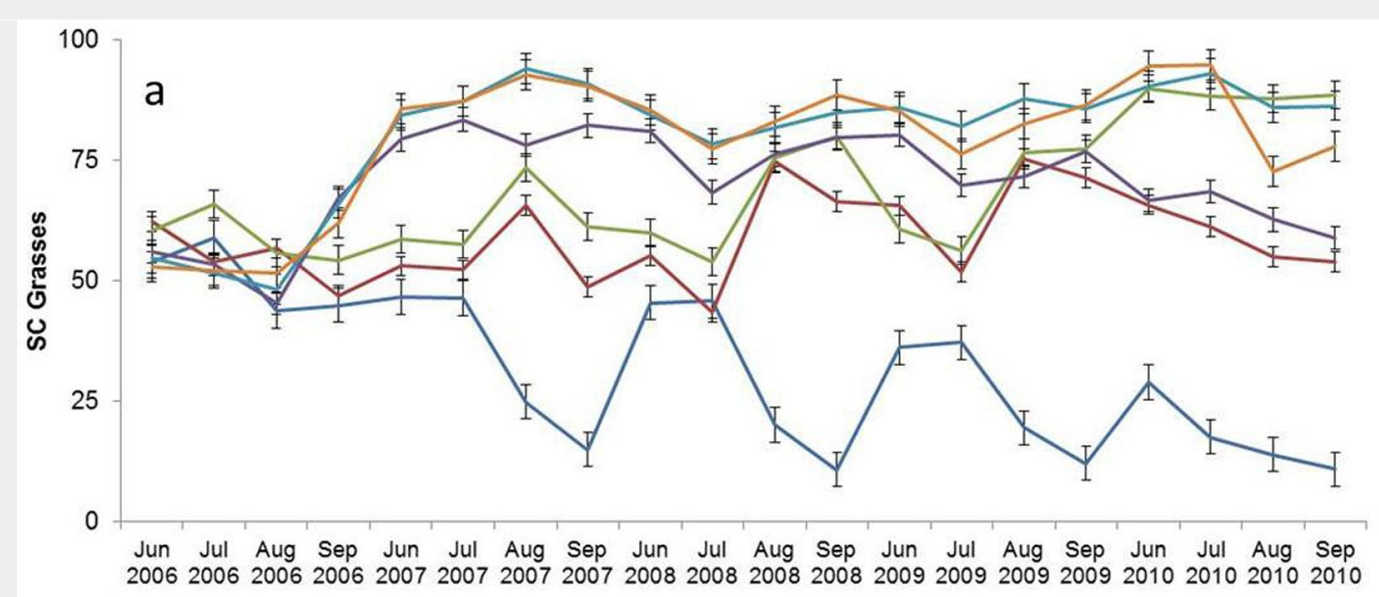

Fig. 4 - Effect of the interaction between sowing and the number of cuts on the specific contributions (SC) of (a) grasses and (b) forbs over the whole sampling period (2006-2010). Lines represent the evolution through time of the SC parameter in the different treatments. Error bars represent the standard error.

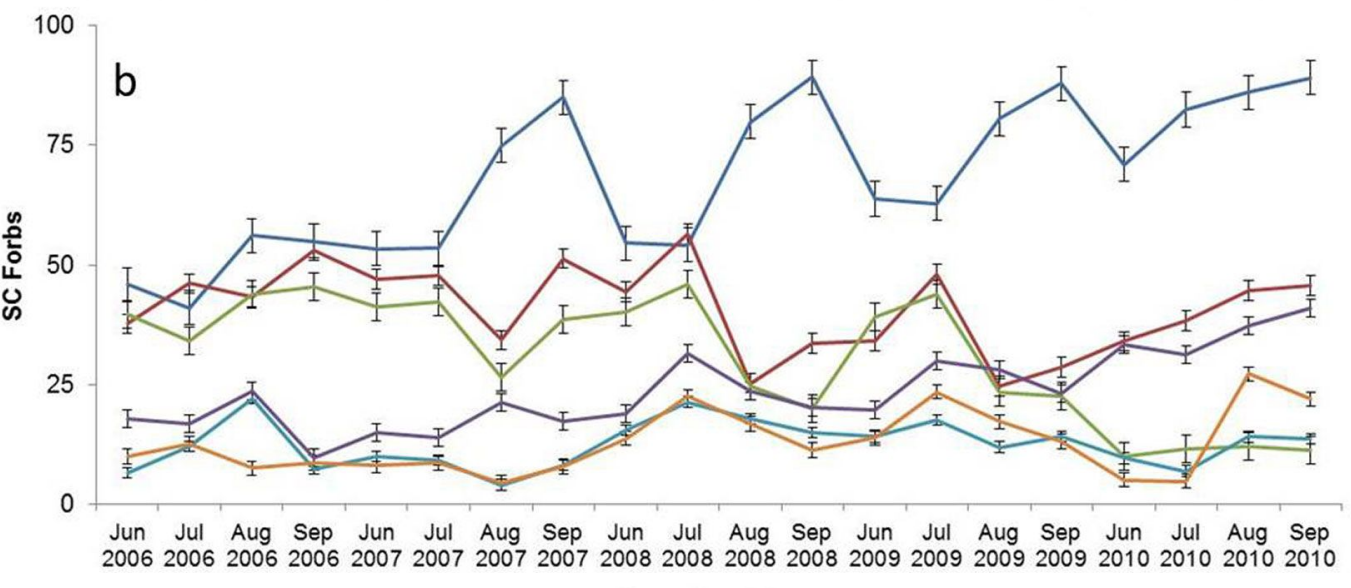
Sampling dates

-No sowing - 0 cuts - No sowing -1 cut - No sowing -2 cuts
- Sowing - 0 cuts - Sowing - 1 cut

at least 1 cut allowed non-sown plots to with no cuts. As expected, the effect of the (especially those not subjected to sowing), reach values similar to those observed in same treatments on the $S C$ of forbs (Fig. with percentage reaching nearly $90 \%$ at the the sown plots. At the end of the experi- 4b) was the opposite. Over time, a proment, the effect of 2 cuts on non-sown gressive increase in the presence of forbs plots was remarkable, so that the $S C$ of (mainly represented by bracken) was regrasses was higher than that of sown plots corded in the plots not subjected to cuts last sampling date. At the end of the experiment, the percentage of forbs in sown plots not subjected to any cuts was comparable to that of non-sown plots that had

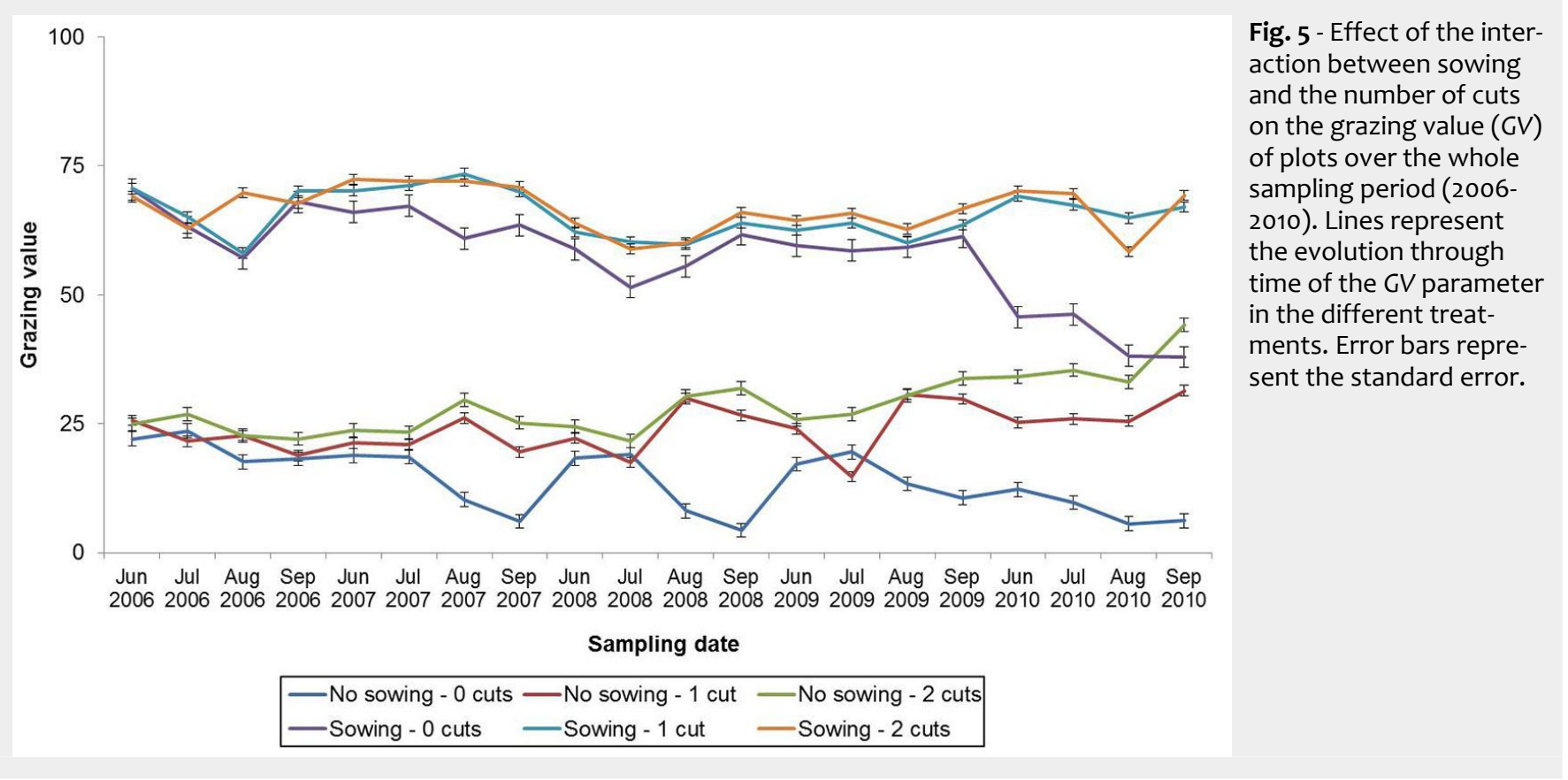


been cut once. Overall, the best performances were obtained by sown plots (cut once or twice a year) and non-sown plots that had been subjected to two cuts.

Sowing and/or cutting effects on the grazing value $(G V)$ of the investigated plots were less remarkable at the beginning of the experiment than at the end (Fig. 5). It is worth to notice that this parameter is highly affected by sowing that introduced species of remarkable forage interest, thereby sown plots showed very high values, regardless of the cutting regime. Indeed, non-sown plots not subjected to any cuts had very low $G V$ (nearly 5) both in the second year and at the end of the experiment. In contrast, non-sown plots undergone to 1 or 2 cuts showed acceptable grazing values. The effects of sowing on uncut plots was maintained for a long period. Only at the end of the experiment the performance of non-sown plots that had been cut twice was comparable to sown plots that had not been subjected to any cuts. With regards to grazing value, sown plots, cut once or twice, achieved better results over the entire duration of the experiment.

\section{Discussion}

The trial was carried out to systematically analyze the effect of different agronomic interventions on the improvement of sward composition in open areas within a beech forest and encroached by Pteridium aquilinum. The survey carried out over a long period (5 years) allowed a proper assessment of the effects of the different treatments (sowing and/or cutting) on the main grassland characteristics (Tocco et al. 2013).

The positive effect of sowing was evident; particularly, an increase in the presence of the main forage families (grasses and legumes) was observed both in terms of specific contribution and species number, thus raising the grazing value of the sown plots. This result, of course, could be partially due to the presence of forage species in the original sowing mixture. Moreover, ploughing before sowing caused a large reduction in forbs (particularly bracken) by removing their rhizomes and thus limiting possible resprouting. Therefore, grassland improvement seem to be related to both a positive effect on canopy renovation and a detrimental effect on bracken. The reduction of forbs, that generally have no forage interest, has proven to be an important factor in improving the botanical composition of pastures and the quality of swards (Pakeman et al. 2002).

Sowing after ploughing led to the reappearance of other species in the sward, which were previously inhibited by the presence of the bracken. Similar results were found in a previous study carried out in nearby locations (Cervasio et al. 2007). According to Ward \& Jennings (1990), bracken removal is critical to improve the re-colonization of open areas by sponta- neous species and enhance the ecological parameters of the canopy. Similar results are also reported by Prach et al. (2014), with particular regards to some target botanical species.

Cutting management influenced the presence of botanical families in different ways, as grasses were only influenced by the cut occurrence, regardless of the number, while legumes were significantly increased by 2 cuts a year. This was a direct consequence of the growth habit and heliophilous behavior of legumes (Den Ouden 2000), which can be repressed because of the competition for light by tall species, such as grasses or bracken (Doležal et al. 2011). Legumes were positively affected by the restoration treatment, as already found by previous research in the same area (Argenti et al. 2012). Our data were highly consistent with the results of a study carried out in central Italy (Tuscany), by Messeri et al. (2010), who report the presence of an average number of legume species that is three times higher in improved areas as compared to natural ones. Furthermore, the long-run effect of the cutting regime applied on the specific contribution of forbs followed the same trends reported by Cox et al. (2007), who demonstrated that cutting treatments had a weak effects at the beginning, but that their impact increased during the following period, especially by cutting twice a year. In general, to enhance the botanical composition of the sward, we observed that it should be mowed twice. Indeed, by applying only a single cut, the presence of forbs demonstrated a decreasing trend. Consequently, cutting once a year could be a useful practice to optimize the exploitation of open areas by wild ungulates, which also feed on spontaneous species not necessarily utilized by livestock (Cervasio et al. 2009). The effects of the cutting regime were greater in non-sown plots, as sowing produced remarkable changes in the vegetation composition; therefore, the importance of the cutting treatment on natural grassland in our case is greater that on sown ones, and this increases in importance over time. Hence, our findings are consistent with Wilsey \& Martin (2015), who stated that a reduced utilization can mimic the grazing behavior of wild animals, thus maintaining a certain level of diversity in grassland-dominated habitats.

Nevertheless, we observed a significant increase in the grazing value of pastures with only 1 annual cut. This was likely due to the reduction of competition exerted by either bracken or other invasive species. Even a single cut may restrain the negative action of shade by bracken fronds on heliophilous species (such as legumes), which are often characterized by highly specific indexes and contribute to increase the pastoral importance of the sward. This confirms the results obtained in similar habitats by Messeri et al. (2010), who detected a higher grazing value in restored grass- lands subjected to 1 cut per year as compared with natural areas, which were mainly encroached by bracken. The close and inverse relationship between the presence of bracken and $G V$ was already found in the same area by Argenti et al. (2012). Therefore, an efficient and cost-effective improvement of grasslands in this area can be achieved by applying a single mechanical intervention. In fact, maintenance actions are considered as one of the main factors contributing to the prolongation of the effects of original habitat restoration (Cervasio 2009). Cox et al. (2008) highlighted the importance of cutting twice a year to maintain the prolonged effectiveness of the treatment. Therefore, the adoption of regular programmes of maintenance are strongly encouraged for an efficient and long-lasting recovery of areas encroached by bracken (Pakeman et al. 2002), once the control operations are accomplished (Le Duc et al. 2000b).

\section{Conclusions}

According to previous findings, this fiveyear experiment confirms the efficacy of cuttings and/or sowing in the restoration of grasslands invaded by bracken. We demonstrated that the above agronomic factors highly affect both grazing value and vegetation dynamics of the studied pastures.

Soil tillage followed by sowing of a suitable forage mixture led to an effective improvement in the grassland and a better control of bracken. The mixture sown did enhance the quality of the grassland by increasing $G V$, which was almost threefold higher than that of non-sown plots. This also had a positive effect on floristic richness and biodiversity of the sward.

The number of cuts applied was crucial for the long-term maintenance of the grassland botanical composition and the quality of the pasture. Remarkable reduction in bracken abundance and significant improvement in grazing value were observed with just one yearly cut. This means that one cut could be an effective and economic practice for grassland improvement even when the use of tillage for seedbed preparation is impractical or unfeasible, e.g., wherever the surface of areas free of wood is reduced. After some years of cuttings, we observed that the overall vegetation composition and the general grazing value were similar to the sown areas not subjected to any cuts. Moreover, cutting is the only method to improve pastures in protected areas, where chemical products cannot be used, as well as in areas where it is not possible to use domestic animals.

Our results confirmed that a regular and continued maintenance of the recovered areas is needed to preserve the results achieved by the improvements. In fact, a progressive increase over time in the difference between plots subjected to 1-2 cuts and those uncut was observed, particularly in non-recovered grasslands. This was 
mainly due to the presence of bracken, which had the following consequences: (i) depression of legumes and other species with high palatability; (ii) reduction of colonization by autochthonous species; (iii) worsening of the quality of pastures, often making open areas inside the forests completely unfit for wildlife.

\section{Acknowledgments}

This research was supported by a grant from the Parco dei Laghi di Suviana e Brasimone (Bologna, Italy). The authors thank Vanessa Di Leo, Chiara Crocetti, Alessandro Messeri, Leonardo Gori and Marco Ferretti, for their essential help in carrying out the fieldwork and data collection. Special thanks to the staff of the Regional Park "Laghi di Suviana e Brasimone", especially to Lucia Bolognesi and Antonella Gallo, for their assistance and support in the fieldwork. The authors would also like to thank two anonymous reviewers for their helpful comments, which improved the quality of the original manuscript.

\section{References}

Alday JG, Cox ES, Pakeman RJ, Harris MPK, Le Duc MG, Marrs RH (2012). Overcoming resistance and resilience of an invaded community is necessary for effective restoration: a multisite bracken control study. Journal of Applied Ecology 50: 156-167. - doi: 10.1111/1365-2664.12 015

Argenti G, Cervasio F, Ponzetta M (2012). Control of bracken (Pteridium aquilinum) and feeding preferences in pastures grazed by wild ungulates in an area of the Northern Apennines (Italy). Italian Journal of Animal Science 11: 336341. - doi: 10.4081/ijas.2012.e62

Argenti G, Lombardi G (2012). The pasture-type approach for mountain pasture description and management. Italian Journal of Agronomy 7: 293-299. - doi: 10.4081/ija.2012.e39

Bagella S, Salis L, Marrosu GM, Rossetti I, Fanni S, Caria MC, Roggero PP (2013). Effects of longterm management practices on grassland plant assemblages in Mediterranean cork oak silvopastoral systems. Plant Ecology 214: 621-631. doi: 10.1007/s11258-013-0194-x

Birch CPD, Vuichard N, Werkman BR (2000). Modelling the effects of patch size on vegetation dynamics: bracken [Pteridium aquilinum (L.) Kuhn] under grazing. Annals of Botany 85 (Supplement 2): 63-76. [online] URL: http:// aob.oxfordjournals.org/content/85/suppl_2/63. short

Cantiani MG, Talamucci P (1985). Tentativi di controllo della felce Pteridium aquilinum (L.) Kuhn con interventi "leggeri" in Irpinia. [Control of bracken Pteridium aquilinum (L.) Kuhn with "light" interventions in Irpinia]. L'Italia Forestale e Montana 40:337-365. [in Italian]

Cavallero A, Aceto P, Gorlier A, Lombadi G, Lonati M, Martinasso B, Tagliatori C (2007). I tipi pastorali delle Alpi piemontesi. [Pasture vegetation types in Piedmont Alps]. Alberto Perdisa Editore, Bologna, Italy, pp. 467. [in Italian]

Cavallero A, Rivoira G, Talamucci P (2002). Pascoli. [Pastures]. In: "Coltivazioni erbacee. For- aggere e tappeti erbosi" (Baldoni R, Giardini L eds). Patron Ed., Bologna, Italy, pp. 239-294. [in Italian]

Cervasio F (2009). Recupero e valorizzazione della potenzialità pabulare di aree aperte in zone collinari e montane dell'Appennino. [Recovery and valorization of forage quality of open areas in hilly and mountainous environments of Apennines]. PhD thesis, University of Firenze, Firenze, Italy, pp. 84. [in Italian]

Cervasio F, Ponzetta MP, Argenti G, Di Leo V (2007). Environmental improvement and conservation of useful pastures for wild herbivores in a Regional Park on the Apennine Mountains. Italian Journal of Animal Science 6 (Supplement 1): 842-844.

Cervasio F, Ponzetta MP, Argenti G, Di Leo V, Crocetti C (2009). Feeding evaluation of spontaneous species used by wild ungulates. Italian Journal of Animal Science 8: 286-288. - doi: 10.4081/ijas.2009.s2.286

Cox ES, Marrs RH, Pakeman RJ, Le Duc MG (2007). A multi-site assessment of the effectiveness of Pteridium aquilinum control in Great Britain. Applied Vegetation Science 10: 429-440. doi: 10.1111/j.1654-109X.2007.tboo442.x

Cox ES, Marrs RH, Pakeman RJ, Le Duc MG (2008). Factors affecting the restoration of heathland and acid grassland on Pteridium aquilinum infested land across the UK: a multisite study. Restoration Ecology 16: 553-562. doi: 10.1111/j.1526-100X.2007.00326.x

Daget P, Poissonet J (1969). Analyse phytologique des prairies. [Phytoecological analysis of grasslands]. CNRS-CEPE doc. no. 50, Montpellier, France, pp. 120. [in French]

Daget P, Poissonet J (1972). Un procède d'estimation de la valeur pastorale des pâturages. [A method to assess grazing value of pastures]. Fourrages 49: 31-40. [in French]

Den Ouden J (2000). The role of bracken (Pteridium aquilinum) in forest dynamics. PhD thesis, University of Wageningen, Wageningen, The Netherlands, pp. 218. [online] URL: http://www. cabdirect.org/abstracts/20003020159.html

Di Tomaso JM, Masters RA, Peterson VF (2010). Rangeland invasive plant management. Rangeland 32: 43-47. - doi: 10.2111/RANGELANDS-D-0900007.1

Doležal J, Mašková Z, Lepš J, Steinbachová D, De Bello F, Klimešová J, Tackenberg O, Zemeke F, Kvtc J (2011). Positive longterm effect of mulching on species and functional trait diversity in a nutrient-poor mountain meadow in Central Europe. Agriculture, Ecosystems and Environment 145: 10-28. - doi: 10.1016/j.agee.2011.01.010 Frankland JC (1976). Decomposition of bracken litter. Botanical Journal of the Linnean Society 73: 133-143. - doi: 10.1111/j.1095-8339.1976.tbo20 18. $\mathrm{x}$

Genghini M, Capizzi D (2005). Habitat improvement and effects on brown hare Lepus europaeus and roe deer Capreolus capreolus: a case study in northern Italy. Wildlife Biology 11: 319-329. - doi: 10.2981/0909-6396(2005)11[319: HIAEOB]2.0.CO;2

Godefroid S, Monbaliu D, Massant W, Van Der Aa B, De Vos B, Quivyc V, Koedam N (2007). Effects of soil mechanical treatments combined with bramble and bracken control on the restoration of degraded understory in an ancient beech forest. Annals of Forest Science 64: 321-331. - doi: 10.1051/forest:2007009 Gomez KA, Gomez AA (1984). Statistical procedures in agricultural research ( $\left.2^{\text {nd }} e d n\right)$. John Wiley and Sons, New York, USA, pp. 680.

Laiolo P, Pondero F, Ciliento E, Rolando A (2004). Consequences of pastoral abandonment for the structure and diversity of the alpine avifauna. Journal of Applied Ecology 41: 294-304. - doi: 10.1111/j.0021-8901.2004.00893.x Le Duc MG, Pakeman RJ, Marrs RH (2000a). Vegetation development on upland and marginal land treated with herbicide for bracken (Pteridium aquilinum) control in Great Britain. Journal of Environmental Management 58: 147-160. - doi: 10.1006/jema.1999.0321

Le Duc MG, Pakeman RJ, Putwain PD, Marrs RH (200ob). The variable responses of bracken fronds to control treatments in Great Britain. Annals of Botany 85: 17-29. - doi: 10.1006/anbo. 1999.1052

Le Duc MG, Pakeman RJ, Marrs RH (2003). Changes in the bracken rhizome system subjected to long-term experimental treatment. Journal of Applied Ecology 40: 508-522. - doi: 10.1046/j. 1365-2664.2003.00818.x

Lengyel $S$, Déri $E$, Varga Z, Horváth R, Tóthmérész $B$, Henry PY, Kobler A, Kutnar L, Babij V, Selinkar A, Christia C, Papastergiadou E, Gruber B, Henle K (2008). Habitat monitoring in Europe: a description of current practices. Biodiversity and Conservation 17: 3327-3339. - doi: 10.10 07/s10531-008-9395-3

Lowday JE, Marrs RH (1992). Control of bracken and the restoration of heathland. III. Bracken litter disturbance and heathland restoration. Journal of Applied Ecology 29: 212-217. - doi: 10.2307/2404363

Mack R, Simberloff D, Lonsdale W, Evans H, Clout M, Bazzaz F (2000). Biotic invasions: causes, epidemiology, global consequences, and control. Ecological Applications 10: 689-710. doi: 10.1890/1051-0761(2000)010[0689:BICEGC] 2.0.CO;2

Marrs RH, Lowday JE, Jarvis L, Gough MW, Rowland AP (1992). Control of bracken and the restoration of heathland. IV. Effects of bracken control and heathland restoration treatments on nutrient distribution and soil chemistry. Journal of Applied Ecology 29: 218-225. - doi: 10.2307/2404364

Marrs RH, Le Duc MG, Mitchell R, Goddard D, Paterson S, Pakeman R (2000). The ecology of bracken: its role in succession and implications for control. Annals of Botany 85 (Suppl. B): 315. - doi: 10.1006/anbo.1999.1054

Marrs RH, Watt A (2006). Biological flora of Pteridium aquilinum (L.) Kuhn. Journal of Ecology 94: 1272-1322. - doi: 10.1111/j.1365-2745.2006.0 1177.x

McAllister MM, Schooley RL, Bestelmeyer BT, Coffman JM, Cosentino BJ (2014). Effects of grassland restoration efforts on mound-building ants in the Chihuahuan Desert. Journal of Arid Environments 111: 79-83. - doi: 10.1016/j. jaridenv.2014.08.005

Messeri A, Ponzetta MP, Cervasio F, Crocetti C, Gori L, Argenti G (2010). Habitat improvements with agronomic treatments for ungulates in an area of central Italy. In: Proceedings of the " 23 th General Meeting of European Grassland 
Federation" (Schnyder $\mathrm{H}$ et al eds). Kiel (Germany), 29 Aug-2 Sep 2010. Mecke Druck und Verlag, Duderstadt, Germany, pp. 767-769. [online] URL: http://www.cabdirect.org/abstrac ts/20103325794.html

Pakeman RJ, Le Duc MG, Marrs RH (2002). A review of current bracken control and associated vegetation strategies in Great Britain. Web Ecology 3: 6-11. - doi: 10.5194/we-3-6-2002

Pakeman RJ, Marrs RH (1992). The conservation value of bracken Pteridium aquilinum (L.) Kuhn dominated communities in the UK, and an assessment of the ecological impact of bracken expansion and removal. Biological Conservation 62: 101-114. - doi: 10.1016/0006-3207(92)90 931-C

Peeters A (2008). Challenges for grasslands, grassland-based systems and their production potential in Europe. In: Proceedings of the " $22^{\text {th }}$ General Meeting of European Grassland Federation" (Hopkins et al. eds). Uppsala (Sweden), 9-12 June 2008. SLU Repro, Sweden, pp. 9-24. [online] URL: http://www.researchgate.net/pu blication/234001786

Pienkowski MW, Watkinson AR, Kerby G, Marrs RH, Johnson SW, Le Duc MG (1998). Control of bracken and restoration of heathland. VI. The response of bracken fronds to 18 years of continued bracken control or 6 years of control followed by recovery. Journal of Applied Ecology 35: 479-49o. - doi: 10.1046/j.1365-2664.1998.354 0479.x

Ponzetta MP, Cervasio F, Crocetti C, Messeri A, Argenti G (2010). Habitat improvements with wildlife purposes in a grazed area on the Apennine Mountains. Italian Journal of Agronomy 5: 233-238. - doi: 10.4081/ija.2010.233

Prach K, Jongepierová I, Rehounková K, Fajmon
K (2014). Restoration of grasslands on ex-arable land using regional and commercial seed mixtures and spontaneous succession: successional trajectories and changes in species richness. Agriculture, Ecosystems and Environment 182: 131-136. - doi: 10.1016/j.agee.2013.06.003

Roggero PP, Bagella S, Farina R (2002). Un archivio di dati di indici specifici per la valutazione integrata del valore pastorale. [Integrated analysis to assess the grazing value of Mediterranean rangelands]. Rivista di Agronomia 36: 149156. [in Italian]

Rook AJ, Tallowin JRB (2003). Grazing and pasture management for biodiversity benefit. Animal Research 52: 181-189. - doi: 10.1051/animres: 2003014

Rossetti I, Bagella S, Cappai C, Caria MC, Lai R, Roggero PP, Martins Da Silva P, Sousa JP, Querner P, Seddaiu G, (2015). Isolated cork oak trees affect soil properties and biodiversity in a Mediterranean wooded grassland. Agriculture, Ecosystems and Environment 202: 203-216. doi: 10.1016/j.agee.2015.01.008

SAS (2003). SAS/STAT software. Release 9.1, SAS Institute Inc., Cary, NC, USA, pp. 5121.

Smart RP, Calver LJ, Crowe AM, Emmerson KM, Cresser MS (2007). Bracken effects on inorganic nitrogen leaching from an upland podzol. Soil Use and Management 23: 317-322. - doi: 10.1111/j.1475-2743.2007.00099.x

Stevens R (2004). Basic considerations for range and wildland revegetation and restoration. General Technical Report RMRS-GTR-136, Chapter 4, Rocky Mountain Research Station, USDA Forest Service, Fort Collins, CO, USA, pp. 19-23. [online] URL: http://www.fs.fed.us/rm/pubs/rm rs_gtr136_1/rmrs_gtr136_1_019_024.pdf Stewart G, Cox E, Le Duc MG, Pakeman R, Pullin
A, Marrs RH (2008). Control of Pteridium aquilinum: meta-analysis of a multi-site study in the UK. Annals of Botany 101: 957-970. - doi: 10.1093 laob/mcno2o

Stewart G, Pullin A, Tyler C (2007). The effectiveness of asulam for bracken (Pteridium aquilinum) control in the United Kingdom: a metaanalysis. Environmental Management 40: 747760. - doi: 10.1007/s00267-006-0128-7

Targetti S, Staglianò N, Messeri A, Argenti G (2010). A state-and-transition approach to alpine grasslands under abandonment. iForest Biogeosciences and Forestry 3: 44-51. - doi: 10.3832/iforo525-003

Tocco C, Probo M, Lonati M, Lombardi G, Negro M, Nervo B, Rolando A, Palestrini C (2013). Pastoral practices to reverse shrub encroachment of sub-alpine grasslands: dung beetles (coleoptera, scarabaeoidea) respond more quickly than vegetation. PLoS ONE 8 (12): e83344. - doi: 10.1371/journal.pone.0083344

Ward LK, Jennings RD (1990). Succession of disturbed and undisturbed chalk grassland at Aston Rowant National Nature Reserve: details of changes in species. Journal of Applied Ecology 27: 913-923. - doi: 10.2307/2404386

Wilsey BJ, Martin LM (2015). Top-down control of rare species abundances by native ungulates in a grassland restoration. Restoration Ecology 23: 465-472. - doi: 10.1111/rec.12197

Zechmeister HG, Schmitzberger I, Steurer B, Peterseil J, Wrbka T (2003). The influence of land-use practices and economics on plant species richness in meadows. Biological Conservation 114: 165-177. - doi: 10.1016/Sooo6-3207(03) 00020-X 